\title{
Gejala Media Sosial Twitter Sebagai Media Sosial Alternatif
}

\author{
Irfani Zukhrufillah \\ Program Studi Ilmu Komuninasi, Fakultas Ilmu Sosial \& Budaya \\ Universitas Gajayana Malang, 65144, Indonesia \\ zeze.fany@gmail.com
}

INFO ARTIKEL

Riwayat Artikel:

Diterima Desember 2017

Direvisi Januari 2018

Disetujui Februari 2018
ABSTRAKSI

\begin{abstract}
Abstrak: Kajian ini tertujuan untuk mengetahui sejarah perkembangan teknologi komunikasi hingga memasuki era digital dan social media. Terlebih media social twitter yang perkembangannya pesat dan pengguna di Indonesia pun mengalami kenaikan yang semakin signifikan. Kajian ini menggunakan landasan teori peluru dan agenda setting. Hasilnya dapat dilihat bahwa dari gejala-gejala yang muncul, dapat dikatakan bahwa twitter menjadi media alternative setelah para pendahulunya seperti radio, televisi dan koran. Penyebutan sebagai media alternatif ini bukan tanpa bukti. Para penggunanya yang semakin besar juga diwujudkan dalam keaktifan mereka dalam mentweet kegiatan sehari-hari. Bahkan tidak jarang para follower mengetahui berita tentang seseorang dari twitter. Para pengguna juga semakin berlomba mendapatkan follower demi verifikasi yang dilakukan oleh twitter sendiri.
\end{abstract}

Kata Kunci:

Gejala media sosial,

Twitter,

Media alternatif

Keywords:

Symptoms of social media,

Twitter,

Alternative media
Abstract : This study aims to know the history of the development of communication technology in arrival of digital and social media era. Moreover social media twitter that has develop faster and users in Indonesia also increase significantly. This study uses a bullet theory and agenda setting. The results can be seen that from the symptoms that appear, it can be said that twitter became an alternative media after its predecessors such as radio, television and newspapers. The mention of this alternative medium is not without evidence. The larger users are also embodied in their activities in tweeting their daily activities. In fact, not infrequently the follower knows news about someone from twitter. The users are also increasingly competing to get follow-up follower by the twitter itself.

\section{Pendahuluan}

Marshall Mc. Luhan mengatakan bahwa kita sebenarnya berada dalam desa global. ${ }^{1}$. Tidak heran rasanya jika dikatakan seperti itu karena kenyataan yang ada sekarang mengindikasikan bahwa setiap orang di dunia ini saling terhubung dengan bantuan media. Diawali dari kebutuhan manusia untuk berkomunikasi antar sesamanya, banyak penemuan yang dilakukan untuk memenuhi kebutuhan tersebut. Sebut saja James Clerk Maxwell pada tahun 1864 yang secara tidak diduga dapat menunjukkan kecepatan cahaya yang diwujudkan dari hubungan antara dua jenis kekerasan.

Dari sini perkembangan teknologi sudah tidak dapat dibendung. Maxwell yang menduga ada gelombang elektromagnetik yang cepat mempengaruhi antara medan magnet listrik dan menyebar dengan kecepatan cahaya. Ia saat itu menduga bahwa sebenarnya cahaya itu seperti gelombang yang merupakan fenomena elektromagnetik. Lebih jauhnya ia menunjukkan bahwa listrik dan medan magnet bepergian melalui ruang, dalam bentuk gelombang. Dia berpendapat bahwa cahaya adalah suatu bentuk radiasi elektromagnetik.

\footnotetext{
${ }^{1}$ Sasa Djuarsa Sendjaja, Teori Komunikasi (Universitas Terbuka: 1994) hal 175.
} 
Perkembangan terhadap teknologi komunikasi pun semakin pesat. Para ilmuwan berlomba untuk menemukan penemuan terbaru terkait dengan pengembangan teknologi komunikasi. Penemuan-penemuan baru ini berikutnya berturut mulai dari radio, televise, computer dan semakin banyak hingga ditemukannya world wide web (www). Setelah penemuan web inilah dunia digital semakin tak dapat dibendung kemajuannya hingga bermunculan handphone yang mempermudah akses terhadap situs-situs web tadi.

Kemunculan www semakin memperluas jaringan internet yang ada di dunia. Penggunanya semakin tumbuh dengan pertumbuhan yang pesat. Internet dengan pengguna 45 juta adalah medium yang terus tumbuh. ${ }^{2}$ Dunia semakin dalam genggaman. Perkembangan teknologi semakin luar biasa dengan segala penemuan barunya. Tidak hanya pada aplikasi-aplikasi internet, namun alat untuk mengunduh aplikasi tersebut juga sudah semakin canggih, luas dan mudah dijangkau. Perkembangan ini tentu menumbuhkan banyak hal termasuk adanya new media. Media massa seperti yang kita tau selama ini adalah media massa cetak dan media massa elektronik.

Kemunculan jejaring sosial berbasis komputer dan handphone nampaknya mendapat perhatian tinggi dari masyarakat. Terbukti dengan semakin banyaknya jejaring sosial yang muncul. Friendster, Facebook, Twitter, Linkd In dan masih banyak lainnya. Masayarakat yang mendapatkan kemudahan dari jejaring sosial tersebut semakin getol dalam menggunakannya.

Masyarakat diberikan banyak suguhan dan bebas memilih dari sekian banyak tipe new media. Mereka memiliki pilihan yang sangat beragam untuk mengkonsumsi media, Web advertising, DVD and CD-ROM media virtual reality environments (Augmented Reality), Integration of digital data with the telephone, such as Internet telephony, digital cameras, Web sites, Streaming audio and video, chat rooms, e-mail, online communities, Social media, Web blog/vlog, Podcasting, SMS/MMS, mobile content.

Perkembangan media dewasa ini menimbulkan persepsi baru tentang pengertian media massa. Hal inilah yang seringkali disebut sebagai new media. Sebagian pakar telah mengkategorikan jejaring social sebagai new media yang memiliki fungsi layaknya media massa lain yang sudah dikenal, seperti radio, televisi, koran dan sebagainya. Selain itu, jejaring social juga telah dikategorikan sebagai media alternatif pelengkap dari media massa pendahulunya. Dalam kajian berikut, jejaring social yang dipilih untuk ditelaah adalah Twitter. Mengingat perkembangannya yang pesat dan menjadi aroma baru dari jejaring yang sebelumnya telah ada seperti Friendster dan Facebook. Untuk itulah kajian mengenai twitter sebagai media alternatif ini dilakukan untuk melihat sejauh manakah penyematan media alternatif layak disematkan.

Sehingga Rumusan Masalah dalam Penelitian ini adalah a) Bagaimana sejarah kemunculan jejaring sosial Twitter? b) Bagaimana perkembangan Twitter di Indonesia? c) Mengapa Twitter digadang-gadang sebagai salah satu media alternatif?

\section{Kajian Pustaka}

\section{A. Tinjauan Pustaka tentang Twitter}

Twitter (/'twitər/) adalah layanan jejaring sosial dan mikroblogdaring yang memungkinkan penggunanya untuk mengirim dan membaca pesan berbasis teks hingga 140 karakter, yang dikenal dengan sebutan kicauan (tweet). Twitter didirikan pada bulan Maret 2006 oleh Jack Dorsey, dan situs jejaring sosialnya diluncurkan pada bulan Juli. Sejak diluncurkan, Twitter telah menjadi salah satu dari sepuluh situs yang paling sering dikunjungi di Internet, dan dijuluki dengan "pesan singkat dari Internet". Di Twitter, pengguna tak terdaftar hanya bisa membaca

\footnotetext{
${ }^{2}$ http://www.viva.co.id, diakses tanggal 20 April 2016
} 
kicauan, sedangkan pengguna terdaftar bisa menulis kicauan melalui antarmuka situs web, pesan singkat (SMS), atau melalui berbagai aplikasi untuk perangkat seluler.3

Kemunculan twitter sendiri tidak dapat dilepaskan dari penemuan teknologi komunikasi terdahulu, seperti radio, televisi hingga internet. Pasca James Clerk Maxwell pada tahun 1864 yang secara tidak diduga dapat menunjukkan kecepatan cahaya yang diwujudkan dari hubungan antara dua jenis kekerasan, berturut kemudian Heinrich Rudolf Hertz bereksperimen dengan gelombang radio di laboratoriumnya pada tahun 1887 , dan dari penelitiannya ia dapat menunjukkan bahwa gelombang elektromagnetik ada dengan keberhasilannya membuat sebuah alat untuk menghasilkan dan mendeteksi VHF atau UHF radio gelombang. Dan kemudian peneliti lain seperti Quqliermo Marconi, Reginald Fessenden, Lee De Forest, david Samoff dan masih banyak yang lainnya dengan penemuannya masing-masing yang semakin menyempurnakan.

Asumsi pokok Dennis McQuail (1987) tentang arti penting media massa:4 1) Media merupakan industri yang berubah dan berkembang yang menciptakan lapangan kerja, barang dan jasa serta menghidupkan industri lain yang terkait. Media juga merupakan industri tersendiri yang memiliki peraturan dan norma-norma yang menghubungkan institusi tersebut dengan masyarakat dan institusi sosial lainnya. Dipihak lain, industri media diatur oleh masyarakat. 2) Manajemen media massa merupakan sumber kekuatan - alat kontrol, manajemen, dan inovasi dalam masyarakat yang dapat didayagunakan sebagai pengganti kekuatan atau sumber daya lainnya. 3) Media merupakan lokasi (atau norma) yang semakin berperan, untuk menampilkan peristiwaperistiwa kehidupan masyarakat, baik yang bertaraf nasional maupun internasional. 4) Media sering kali berperan sebagai wahana pengembangan kebudayaan, bukan saja dalam pengertian pengembangan bentuk seni dan simbol, tetapi juga dalam pengertian pengambangan tata cara, mode, gaya hidup, dan norma-norma. 6) Media telah menjadi sumber dominan bukan saja bagi idividu untuk memperoleh gambaran dan citra realitas sosial, tetapi juga bagi masyarakat dan kelompok secara kolektif. Media juga menyuguhkan nilai-nilai dan penilaian normatif yang dibaurkan dengan berita dan hiburan

Penemun paling fenomenal dalam internet dengan pengenalan world wide web (www) pada tahun 1990 oleh Barners Lee seolah menjadi angin segar baru bagi para penemu. Ketika media massa semakin dibutuhkan oleh masyarakat, peneliti terus berupaya menumbuhkan alternatif baru dalam berkomunikasi karena media massa seolah dikuasi hanya oleh media massa cetak dan media massa elektronik sedangkan kebutuhan semakin meningkat.

Komunikasi massa yang dapat diakses oleh siapa saja memiliki keheterogenan komunikannya. Menurut Herbet Blumer, memberikan ciri tentang karakteristik audience/komunikan sebagai berikut:5 1) Audience dalam komunikasi massa sangatlah heterogen. Artinya mempunyai heterogenitas komposisi atau susunan. Jika ditinjau dari asalnya, mereka berasal dari berbagai kelompok dalam masyarakat. 2) Berisi individu-individu yang tidak tahu atau mengenal satu sama lain. Antar individu itu tidak berinteraksi satu sama lain secara langsung. 3) Mereka tidak mempunyai kepemimpinan atau organisasi formal

Pada perjalanannya muncullah social media yang awalnya digunakan untuk menghubungkan teman se angkatan di sebuah universitas. Namun ternyata aplikasi ini disukai dan mendapat respon yang baik sehingga semakin dikembangkan. Sebut saja Friendster, Facebook, Twitter, Linkd In dan masih banyak lainnya.

\section{B. Perkembangan Twitter di Indonesia}

Masyarakat diberikan banyak suguhan dan bebas memilih dari sekian banyak tipe new media. Mereka memiliki pilihan yang sangat beragam untuk mengkonsumsi media Web advertising, DVD and CD-ROM media virtual reality environments (Augmented Reality), Integration of

\footnotetext{
${ }^{3}$ https://id.wikipedia.org/wiki/Twitter, diakses tanggal 20 April 2016

${ }^{4}$ Sasa Djuarsa Sendjaja, Teori Komunikasi (Universitas Terbuka:1994) hal 181.

${ }^{5}$ Rachmat Kriyantono, Riset Komunikasi. (Jakarta: Kencana: 2009), hal 192
} 
digital data with the telephone, such as Internet telephony, digital cameras, Web sites, Streaming audio and video, chat rooms, e-mail, online communities, Social media, Web blog/vlog, Podcasting, SMS/MMS, mobile content.

Media sosial-media sosial ini awalnya bertujuan mempertemukan teman satu dengan lainnya yang sudah terpisah namun masih merasa membutuhkan kontak satu sama lain. Namun ternyata pada pekembangannya digunakan sebagai ajang eksistensi diri. Banyak ditemukan dalam media sosial tertentu bahwa teman yang dimiliki dalam jejaring sosialnya terkadang bukanlah teman yang pernah ditemui sebelumnya, namun justru dari media sosial itulah mereka kemudian bertemu. Sekalipun ada juga yang hanya memilih untuk berteman di dunia media sosial itu saja tanpa harus bertemu dan berkomunikasi.

Twitter yang merupakan media sosial dan dikategorikan sebagai new media/media alternatif adalah sebuah jaringan informasi yang terdiri dari pesan 140 karakter yang disebut tweet. Ini adalah sebuah cara baru yang mudah untuk menemukan berita terbaru atau apa yang sedang terjadi terutama yang berkaitan dengan hal-hal yang Anda gemari. Twitter didirikan pada bulan Maret 2006 oleh Jack Dorsey, dan situs jejaring sosialnya diluncurkan pada bulan Juli. Kata twitter secara harfiah berarti 'berkicau'. Situs ini mempunyai konsep blog mikro dalam penggunaannya.

Twitter memiliki strategi pengembangan sebagai berikut: ${ }^{6}$ 1) Mempromosikan perusahaan posting blog melalui akun perusahaan. 2) Mengkomunikasikan masalah dukungan media sosial untuk mendukung tim, dan mengadakan evaluasi setelahnya. 3) Membangun reputasi. 4) Mempromosikan jaringan orang lain

Kunci dasar pelaksanaan rencana tersebut dengan menggunakan sistem teman atau yang biasa disebut follower. Kemudian mempromosikan teman dari follower yang satu ke lainnya. Twitter juga akan melihat sejauh mana pengaruh seseorang dengan akunnya terhadap followernya. Twitter juga memiliki halaman ranking untuk melihat sejauh mana di pengguna akun beraktivitas dengan twitternya. Riset penggunatwitter di Indonesia, ${ }^{7}$

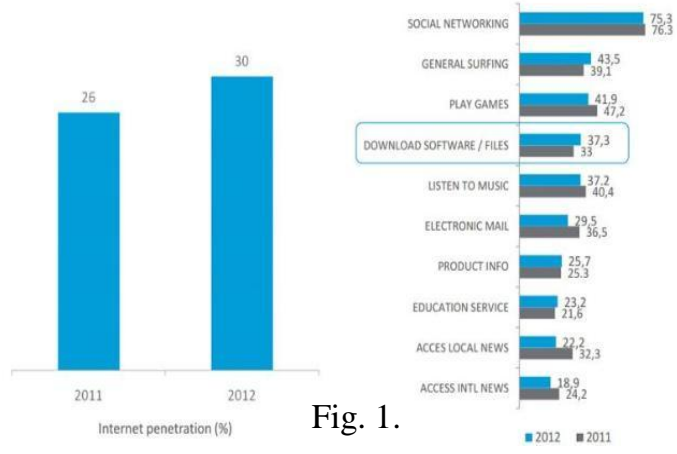

Fig. 2. Riset Pengguna Twitter di Indonesia

Dari riset tersebut dapat dilihat bahwa pertumbuhan pengguna twitter di indonesia mengalami pertumbuhan yang tinggi di segala aspek. Tentu saja bukan tidak mungkin angka ini akan semakin berkembang. Mengingat Twitter menjadi media yang penyebarannya secara digital tidak dapat dibatasi. Bahkan tidak sedikit yang menjelajah daerah bahkan negara lain hanya melalui Twitter. Terlebih jaringan internet ini merupakan jaringan yang mendunia.

\section{Twitter sebagai Salah Satu Media Alternatif}

Para pengguna twitter umumnya melaporkan setiap aktivitasnya. Mereka bahkan semakin terbantu dengan adanya handphone yang semakin canggih. Fitur Twitter sendiri sudha dapat

\footnotetext{
${ }^{6} \mathrm{https}: / /$ pakarkomunikasi.com/sejarah-perkembangan-teknologi-komunikasi, diakses tanggal 20 April 2016

${ }^{7}$ http://static.viva.id/, diakses tanggal 20 April 2016
} 
dinikmati melalui telepon genggam yang artinya semakin tidak dapat lepas dari penggunanya. Inilah yang membuat mereka tidak berhenti melaporkan aktivitasya. Tidak sedikit bahkan yang lebih aktif di Twitter ketimbang di pergaulan nyata.

Follower seolah menjadi sebuah kebanggan tersendiri bagi para penggunanya. Semakin banyak follower maka akan semakin banyak yang dapat membaca aktivitasnya dan dapat mengomentari pula. Semakin banyak komentar dari followers dia merasa banyak yang memperhatikannya. Bahkan saat ini generasi $\mathrm{Z}$ yang merupakan generasi terbanyak sebagai pengguna media sosial ini, lebih banyak menghabiskan waktunya di depan komputer, laptop, notebook dan bahkan smartphone untuk berkomunikasi dengan orang lain. Mereka sudah mengurangi intensitas pertemuan secara fisik dan merasa lebih sreg 'bertemu' teman-temannya di dunia social media yang mereka buat bersama.

Kebanyakan dari pengguna tersebut saat ini berusia sekolah SMA/sederajat. Mereka ini dalam kajian psikologi termasuk dalam generasi Y dan Z. Generasi Y mempunyai ciri-ciri melek teknologi baru. Aktivitas yang mereka lakukan begitu tergantung dengan dunia digital. Mereka menyukai hal yang instan dan cenderung kurang sabar dengan proses rumit yang harus dijalani ketika menjalani sesuatu. Sebuah survey pada kurang lebih 7000-an mahasiswa di Amerika oleh Reynol Junco dan Jeana Mastrodicasa (2007), terungkap bahwa 97\% telah memiliki computer, 94\% memiliki ponsel, 76\%sudah menggunakan fasilitas Instant Messaging, 28\% menulis blog, 44\% membaca blog, $97 \%$ pernah mengunduh music melalui peer to peer_file sharing, $75 \%$ memiliki akun Facebook, 60\%mempunyai beragam tipe portable musik/video : seperti iPod.

Sedangkan generasi $\mathrm{Z}$ disebut juga dengan Platinum Generation. Generasi ini lahir di masa keterbukaan telnologi, cara berpikir, berperilaku, serta adanya sarana pendidikan yang jauh lebih baik. Beberapa karakteristik umum dari Generasi Z diantaranya adalah: 1) Fasih Teknologi. Mereka adalah "generasi digital" yang mahir dan gandrung akan teknologi informasi dan berbagai aplikasi komputer. Mereka dapat mengakses berbagai informasi yang mereka butuhkan secara mudah dan cepat, baik untuk kepentingan pendidikan maupun kepentingan hidup kesehariannya. 2) Sosial. Mereka sangat intens berkomunikasi dan berinteraksi dengan semua kalangan, khususnya dengan teman sebaya melalui berbagai situs jejaring, seperti: FaceBook, twitter, atau melalui SMS. Melalui media ini, mereka bisa mengekspresikan apa yang dirasakan dan dipikirkannya secara spontan. Mereka juga cenderung toleran dengan perbedaan kultur dan sangat peduli dengan lingkungan. 3) Multitasking. Mereka terbiasa dengan berbagai aktivitas dalam satu waktu yang bersamaan. Mereka bisa membaca, berbicara, menonton, atau mendengarkan musik dalam waktu yang bersamaan. Mereka menginginkan segala sesuatunya dapat dilakukan dan berjalan serba cepat. Mereka tidak menginginkan hal-hal yang bertele-tele dan berbelit-belit.

Jadi dapat dilihat kesinambungan antara pekermbangan teknologi dengan para penggunanya yang mayoritas termasuk dalam gen Z. Gen $\mathrm{Z}$ ini begitu tertarik menjukkan eksistensi dirinya melalui situs-situs jejaring sosial di antaranyatwitter. Dalam twitter hal-hal apapun bahkan yang bersifat sepele dan mungkin harusnya menjadi konsumsi pribadi, dirubah begitu saja menjadi konsumsi umum. Mereka merasa setiap yang ada di dirinya layak menjadi perhatian followernya.

Kecenderungan ini tentu memiliki dampak positif dan negatif. Di antara dampak positifnya adalah: 1) Meluasnya jaringan komunikasi dan pertemanan yang dimiliki karena dapat menembus batasan ruang dan waktu. 2) Mendorong diadakannya penelitian lebih lanjut sebagai upaya memnuhi kebutuhan konsumen yang semakin besar. 3) Mendukung kreativitas generasi masa depan.

Di antara dampak negatifnya adalah : 1) Menipisnya kemampuan membedakan antara yang pribadi dan umum. 2) Menimbulkan konflik akibat kicauan yang tidak pada tempatnya dan menyinggung orang lain 3) Menipisnya keinginan mereka untuk berkomunikasi secara fisik dan melakukan aktivitas fisik di luar 


\section{Kajian Teoritik}

Dampak yang ditimbulkan dari jejaring sosial twitter secara disadari atau tidak pasti akan mengikuti setiap perkembangannya. Media sosial memiliki kepentingan untuk membentuk penggunanya. Jika flashback ke masa-masa radio baru ditemukan, TV masih berwarna hitam putih hingga TV tabung pada masa awal-awal ditemukan, media memang memiliki kepentingan untuk mempengaruhi khalayak dengan siaran-siaran yang mereka tayangkan. Entah itu dari segi konten hingga fashion dari artis yang menggunakannya. Inilah yang lantas memunculkan teori di kalangan ahli sebagai teori peluru.

Teori peluru merupakan teori yang menyatakan bahwa media massa merupakan komunikasi searah yang setiap tayangannya memiliki dampak langsung seperti halnya peluru yang dikeluarkan dari senjatanya. Namun seiring dengan perkembangannya, teori ini mendapat bantahan, terlebih setelah diketahui bahwa khalayak semakin memahami dan semakin pintar sehingga mereka dapat memilah dan memilih mana yang akan diikuti dan yang tidak.

Dalam kajian ini, dapat dilihat bahwa seseorang yang memiliki akun twitter berusaha untuk 'memperlihatkan' dirinya di tengah-tengah followernya. Semakin banyak follower ada semacam kebanggaan tersendiri dan muncul perasaan diperhatikan oleh sekitarnya sehinnga ia semakin membutuhkan twitter dalam kehidupan sehari-harinya.

Dari kebutuhan ini, media lantas menyusun agenda yang akan disamapaikannya kepada khalayak untuk mempengaruhi mereka dengn informasi yang disampaikan oleh media. Kajian ini melihat bahwa media sengaja menyusun pesannya agar diikuti. Dalam tataran teoritik, kajian ini merujuk pada teori agenda setting.

Penemu utama teori agenda setting adalah Mxwell McCombs dan Donald Shaw. Mereka menuliskan bahwa audience tidak hanya mempelajari berita-berita dan hal-hal lainnya melalui media massa tetapi juga mempelajari seberapa besar arti pesan tersebut bagi mereka. Masyarakat memiliki pilihan atas apa yang disajikan. ${ }^{9}$

Dalam media social twitter, pemilik akun berhak untuk menfollow dan unfollow orang lain. Ia juga berhak memilih mana tweet yang mau mereka komen dan yang tidak. Termasuk mana tren dan komunitas yang akan mereka masuki atau tinggalkan.

Asumsi dari teori agenda setting menjadi lebih mudah dipahami dan relative mudah juga pengujiannya. Dasar pemikiran dari teori ini adalah, di antara skeian banyak informasi yang dikeluarkan oleh media manakah yang lebih banyak mendapat perhatian dari khalayak. Semakin banyak respon dari khalayak, maka dapat disimpulkan bahwa isu tersebut disukai dan dianggap penting dalam suatu periode tertentu.

Twitter memiliki kebijakan seperti misalnya dapat menyatakan keaslian akun tersebut ketika aktivitasnya banyak dan memiliki banyak follower. Twitter akan melakukan verifikasi dan menyatakan bahwa akun tersebut asli. Hal ini biasanya terjadi pada artis-artis pengguna twitter. Di Indonesia sendiri sudah ada beberapa akun akun yang diverifikasi, seperti misalnya Sherina Munaf dengan akun twitter @ sherinamunaf atau Agnez Monica dnegan akunnya @agnezmo dan beberapa artis lainnya.

Bukti verifikasi dari twitter ini seolah-olah menjadi 'keramat' menurut penulis karena akun yang sudah mendapat tanda centang biru yang berarti telah diverifikasi memiliki prestige tersendiri bagi pemilik akunnya. Inilah yang menjadikan pemilik akun twitter akan lebih aktif untuk agar dapat mendapatkan tanda tersebut. Sekalipun misalnya pengguna akun tidak mendapatkan tanda tersebut, ia akan bangga ketika melihat akunnya di follow oleh banyak orang.

\footnotetext{
${ }^{8}$ Rachmat Kriyantono, Riset Komunikasi. (Jakarta: Kencana: 2009), hal 56

${ }^{9}$ Sasa Djuarsa Sendjaja, Teori Komunikasi (Universitas Terbuka:1994) hal 175
} 
Pesan tidak langsung yang dibuat oleh twitter ini pada akhirnya mampu menjadikan twitter yang termasuk dalam pendatang baru di dunia social media mampu menempati rangking kedua sebagai media social dengan pengguna terbanyak kedua setelah facebook.

Strategi yang sengaja dibuat oleh twitter ini mampu diterima secara luas masyarakat sehingga pesan dan pengaruh yang hendak ia sodorkan kepada khalayak dapat diterima. Namun tentunya dalam agenda setting, pesan/pengaruh yang sengaja dibuat media memang mempengaruhi khalayak namun baru sampai pada tataran kognitif. Untuk tahap penerimaan sepenuhnya berada pada kehendak khalayak.

Dalam kajian teori berikutnya, tahapan penerimaan khalayak terhadap media terhadap pengaruh media massa dibahas dalam teori difusi inovasi. Teori ini menjelaskan bahwa proses adopsi sebuah inovasi memiliki proses. Proses adopsi dalam teori difusi inovasi adalah:

Tahap pengetahuan. Dalam tahapan ini, individu akan menyadari adanya inovasi. Dalam tataran media social, khalayak mengetahui bahwa ada sebuah media social baru dengan kategori dan perbedaannya dengan yang lain.

Tahap persuasi. Dalam tahap ini, khalayak akan menentukan setuju atau tidak setuju dengan inovasi tersebut. Twitter misalnya, seseorang akan memilih menggunakan twitter ketika ia setuju dengan aplikasi yang disajikan. Ia akan memutuskan untuk membuat dan aktif mempergunakan akunnya atau memilih media social lainnya yang sangat beragam dengan kekhasannya masingmasing.

Tahap keputusan. Dalam tahapan ini individu sampai pada tahap memutuskan mana yang digunakan dan mana yang ditinggalkan. Dalam kasus twitter, sebagian khalayak yang memilih membuat akun adalah khalayak yang setuju. Namun sebagian lain yang tidak setuju akan memilih media social lain seperti misalnya facebook, linkdIn dan lainnya.

Tahap konfirmasi. Dalam tahap ini individu mencari pendapat yang menguatkan pilihannya tersebut. Mereka yang memilih aktif di twitter memiliki alasan tertentu, seperti lebih mudah aksesnya, lebih simple dan tidak bertele-tele. Namun sama halnya seperti dengan individu yang menolak. Dia pun juga memiliki alasan mengapa tidak menggunakan twitter, seperti misalnya terlalu umum, kurang bisa detail atau alasan-alasan lainnya.

Twitter memang menjadi fenomena tersendiri.media social ini selain bisa menempati posisi kedua dalam jumlah pemilik akunnya, juga termasuk media social yang sering diekspos oleh media massa lainnya. Banyak artis yang menggunakan twitter sehingga banyak pula reporter yang seringkali mencari informasi tentang kegiatan para artis dari tweets yang di update oleh artis-artis tersebut

\section{Kesimpulan}

Dari pembahasan-pembahasan di atas, Dari kajian ini dapat disimpulkan beberapa hal, di antaranya:

Perkembangan teknologi komunikasi menjadi pemula dari masuknya era digital di dunia saat ini. Dalam perjalanannya muncullah social media yang awalnya digunakan untuk menghubungkan teman se angkatan di sebuah universitas. Namun ternyata aplikasi ini disukai dan mendapat respon yang baik sehingga semakin dikembangkan. Sebut saja Friendster, Facebook, Twitter, Linkd In dan masih banyak lainnya. Hal ini tentu saja menjadi angin segar bagi para penggunanya mengingat mereka mendapat kemudahan pergaulan serta mendapatkan aksesbilitas yang semakin tidak terjangkau.

Pertumbuhan pengguna Twitter di indonesia mengalami pertumbuhan yang tinggi di segala aspek. Tentu saja bukan tidak mungkin nilai ini akan semakin berkembang. Mengingat Twitter menjadi media yang penyebarannya secara digital tidak dapat dibatasi. Bahkan tidak sedikit yang 
menjelajah daerah bahkan negara lain hanya melalui Twitter. Terlebih jaringan internet ini merupakan jaringan yang mendunia.

Seseorang yang memiliki akun twitter berusaha untuk 'memperlihatkan' dirinya di tengahtengah followernya. Semakin banyak follower ada semacam kebanggaan tersendiri dan muncul perasaan diperhatikan oleh sekitarnya sehinnga ia semakin membutuhkan twitter dalam kehidupan sehari-harinya.Semua pengguna semakin berlomba untuk mendapatkan banyak follower. Followes yang banyak memiliki prestige tersendiri bagi pemilik akunnya. Inilah yang menjadikan pemilik akun twitter akan lebih aktif untuk mendapatkan perhatian lebih sehingga followernya akan bertambah.

Kemajuan era digital sudah tidak dapat dibendung lagi. Hal ini tentu memiliki dampak positif. Namun sebagian dari perkembangan ini juga memiliki dampak negatif. Untuk itulah menjadi penting untuk mengadakan pematangan pola berpikir bagi para pengguna twitter untuk menggunakannya sebagaimana mestinya. Terlebih jika melihat penggunanya merupakan generasi $\mathrm{Y}$ dan $\mathrm{Z}$ yang rentang usianya berada pada usia labil dan masih mudah terombang-ambing dalam perkembangan zaman.

Untuk itulah pendampingan baik dari rumah maupun sekolah juga perlu ditingkatkan. Pemerintah juga harus turut andil dalam pendampingan tersebut agar supaya generasi milenial yang melek digital ini dapat memanfaatkan teknologi pada tempatnya.

\section{DAFTAR PUSTAKA}

Arifin, Anwar , "Ilmu Komunikasi Sebuah Pengantar Ringkas", PT. Raja Grafindo Persada, Jakarta; 1995

Barthes, Roland, Elemen-elemen Semiologi. (Jalasutra, Yogyakarta: 2012)

Kriyantono, Rachmat. Riset Komunikasi. (Jakarta: Kencana: 2009).

Ritzher, George Douglas J. Goodman, Teori Sosiologi Modern: Edisi keenam, (Kencana:Jakarta:2011)

Sendjaja, S. Djuarsa. Teori Komunikasi. (Jakarta: Universita Terbuka: 1994).

\section{Sumber Website:}

https://pakarkomunikasi.com/sejarah-perkembangan-teknologi-komunikasi

https://id.wikipedia.org/wiki/Twitter

http://www.viva.co.id/other/cerita-anda/292439-data-dan-fakta-pengguna-twitter-di-indonesia

https://shaktidarikhwan.wordpress.com/2014/09/29/new-media-definisi-pandangan-manfaatkomponen-aplikasi-dan-menganalisa-serta-menjelaskan-fitur-dari-new-media/ 